\title{
Addition of Isocyanide-containing Amino Acids to the Genetic Code for Protein Labelling and Activation
}

Yuda Chen ${ }^{\mathrm{a}}$, Kuan-Lin Wu ${ }^{\mathrm{a}}$, Juan Tang ${ }^{\mathrm{a}}$, Axel Loredo ${ }^{a}$, Jordan Clements ${ }^{\mathrm{a}}$, Jingqi Pei ${ }^{\mathrm{b}}$, Zane Peng ${ }^{b}$, Ruchi Gupta ${ }^{a}$, Xinlei Fang ${ }^{a}$, Han Xiao ${ }^{\text {abc* }}$

${ }^{a}$ Department of Chemistry, Rice University, 6100 Main Street, Houston, Texas, 77005, United States ${ }^{b}$ Department of Biosciences, Rice University, 6100 Main Street, Houston, Texas, 77005, United States 'Department of Bioengineering, Rice University, 6100 Main Street, Houston, Texas, 77005, United States 


\section{Materials}

LB agar and 2YT were ordered from BD Difco ${ }^{\mathrm{TM}}$. Isopropyl- $\beta$-D-thiogalactoside (IPTG) was purchased from Anatrace. 412\% Bis-Tris gels for SDS-PAGE were purchased from Invitrogen. QuickChange Lightning Multi Site-Directed Mutagenesis Kit was purchased from Agilent Technologies (Cat. 210515). Oligonucleotide primers were purchased from Integrated DNA Technologies and Eurofins Genomics (Supplementary Table S1 lists the oligonucleotides used in this report). Plasmid DNA preparation was carried out with the GenCatch ${ }^{\mathrm{TM}}$ Plus Plasmid DNA Miniprep Kit and GenCatch ${ }^{\mathrm{TM}}$ Advanced Gel Extraction Kit. BugBuster ${ }^{\mathrm{TM}}$ Protein Extraction Reagent was purchased from Novagen (Cat. 70584). Protease inhibitor Cocktail was purchased from Biotool. Pierce ${ }^{\mathrm{TM}}$ universal nuclease was purchased from Thermo Scientific (Cat. 88700). NiNTA Agarose was obtained from Qiagen (Cat. 30230). Hoechst 33342 was purchased from Life Technologies ${ }^{\mathrm{TM}}$ (Cat. H3570). ATP and DRAQ5 ${ }^{\mathrm{TM}}$ was obtained from Thermo Scientific. PolyJet transfection reagent was from SignaGen Laboratories. Anti-myc antibody was purchased from BioLegend and FITC-conjugated-anti-mouse antibody was from the Jackson Laboratory. 2-aminoisobutyric acid was obtained from Chem-Impex International. Unless otherwise mentioned, all solvents and chemicals for synthesis were purchased from Alfa Aesar and Fisher Chemical and used as received without further purification.

\section{Synthesis of NCibK and NCK}

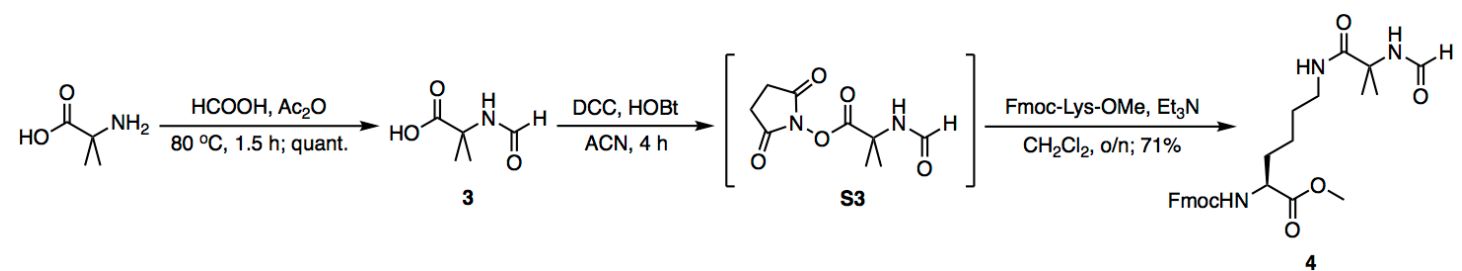

For ease of synthesis, the ester form of NCibK was used in this study. Esterification of the carboxyl group of the lysine derivatives was shown to increase their cellular uptake and intracellular concentration. ${ }^{1}$

2-aminoisobutyric acid (2 g, $19.4 \mathrm{mmol})$ in formic acid $(24 \mathrm{~mL})$ was added to acetic anhydride $(12 \mathrm{~mL}, 127.2 \mathrm{mmol})$, and the mixture was stirred at $80^{\circ} \mathrm{C}$ for $2 \mathrm{~h}$. The reaction was cooled down to room temperature and treated with water (10 $\mathrm{mL}$ ). The reaction mixture was then evaporated, and dried under vacuum overnight to yield 3 as a white solid ( $2.6 \mathrm{~g}$; quant.). The crude product was used for the next step without further purification. For calculated $[\mathrm{M}+\mathrm{H}]^{+}=132.1$, found $[\mathrm{M}+\mathrm{H}]^{+}=$132.1. To a mixture of $\mathrm{N}$-formyl-2-methyl alanine $3(500 \mathrm{mg}, 3.8 \mathrm{mmol}), \mathrm{N}, \mathrm{N}^{\prime}$-dicyclohexylcarbodiimide $(865 \mathrm{mg}$, $4.2 \mathrm{mmol}$ ) and $\mathrm{N}$-hydroxysuccinimide $\left(483 \mathrm{mg}, 4.2 \mathrm{mmol}\right.$ ) were added to dry $\mathrm{CH}_{3} \mathrm{CN}(25 \mathrm{~mL}$ ) and stirred at room temperature for $3 \mathrm{~h}$. The insoluble side product was removed by filtration, and the solvent was evaporated. The obtained white solid was then dissolved in $\mathrm{CH}_{2} \mathrm{Cl}_{2}(50 \mathrm{~mL})$, followed by the addition of Fmoc-Lys-OMeHCl $(1438 \mathrm{mg}, 3.4 \mathrm{mmol})$ and triethylamine $(772 \mathrm{mg}, 1.1 \mathrm{~mL}, 7.6 \mathrm{mmol})$. The solution was stirred at room temperature overnight. The organic solution was extracted with $1 \mathrm{~N} \mathrm{HCl}$, dried over $\mathrm{MgSO} 4$, and evaporated under reduced pressure. The crude product was purified by column chromatography on silica $\left(1-3 \% \mathrm{MeOH}\right.$ in $\left.\mathrm{CH}_{2} \mathrm{Cl}_{2}\right)$ to yield a white foam $4(1.3 \mathrm{~g} ; 71 \%)$. For calculated $[\mathrm{M}+\mathrm{H}]^{+}=$ 496.2, found $[\mathrm{M}+\mathrm{H}]^{+}=496.2$. 
${ }^{1} \mathrm{H}$ NMR $\left(600 \mathrm{MHz}, \mathrm{CDCl}_{3}\right): \delta 8.02(\mathrm{~s}, 1 \mathrm{H}), 7.76(\mathrm{~d}, \mathrm{~J}=7.5 \mathrm{~Hz}, 2 \mathrm{H}), 7.61(\mathrm{t}, \mathrm{J}=7.0 \mathrm{~Hz}, 2 \mathrm{H}), 7.40(\mathrm{t}, \mathrm{J}=7.4 \mathrm{~Hz}, 2 \mathrm{H}), 7.31(\mathrm{t}, \mathrm{J}=$ 7.4, 3H), $6.52(\mathrm{~s}, 1 \mathrm{H}), 6.31(\mathrm{~s}, 1 \mathrm{H}), 5.68(\mathrm{~d}, \mathrm{~J}=7.5 \mathrm{~Hz}, 1 \mathrm{H}), 4.46-4.35(\mathrm{~m}, 2 \mathrm{H}), 4.33(\mathrm{~m}, 1 \mathrm{H}), 4.21(\mathrm{t}, \mathrm{J}=6.9 \mathrm{~Hz}, 1 \mathrm{H}), 3.74(\mathrm{~s}$, $3 \mathrm{H}), 3.26(\mathrm{q}, \mathrm{J}=6.4 \mathrm{~Hz}, 2 \mathrm{H}), 1.84(\mathrm{~m}, 1 \mathrm{H}), 1.71(\mathrm{~m}, 1 \mathrm{H}), 1.57(\mathrm{~s}, 6 \mathrm{H}), 1.53(\mathrm{~m}, 2 \mathrm{H}), 1.37(\mathrm{~m}, 1 \mathrm{H})$.

${ }^{13} \mathrm{C}-\mathrm{NMR}\left(150 \mathrm{MHz}, \mathrm{CDCl}_{3}\right): \delta 174.0,172.9,161.1,156.1,143.9,143.7,141.3,127.7,127.1,125.1,120.0,66.9,57.3,53.7$, $52.4,47.2,39.1,31.8,28.7,25.2,22.1$.<smiles>C=[N+]C(C)(C)C(=O)NCCCC[C@H](NC(F)F)C(=O)OC</smiles>

$4(1.4 \mathrm{~g}, 2.8 \mathrm{mmol})$ was dissolved in dry $\mathrm{CH}_{2} \mathrm{Cl}_{2}(50 \mathrm{~mL})$ under $\mathrm{N}_{2}$ protection, cooled down by $\mathrm{NaCl}$ ice bath, and successively treated with triethylamine $(1.7 \mathrm{~g}, 2.4 \mathrm{~mL}, 17.0 \mathrm{mmol})$ and phosphorous oxychloride $(1.3 \mathrm{~g}, 0.8 \mathrm{~mL}, 8.5 \mathrm{mmol})$. After stirring for $2 \mathrm{~h}$, the organic solution was washed by saturated $\mathrm{NaHCO}_{3}(\mathrm{aq})\left(3 \times 50 \mathrm{~mL}\right.$ ), dried over $\mathrm{MgSO}_{4}$, evaporated under reduced pressure, and purified by column chromatography on silica ( $3 \% \mathrm{MeOH}$ in $\mathrm{CH}_{2} \mathrm{Cl}_{2}$ ) to yield a white foam 5 (1.07 g; $80 \%)$. For calculated $[\mathrm{M}+\mathrm{H}]^{+}=478.2$, found $[\mathrm{M}+\mathrm{H}]^{+}=478.2$.

${ }^{1} \mathrm{H} \mathrm{NMR}\left(600 \mathrm{MHz}, \mathrm{CDCl}_{3}\right): \delta 7.77(\mathrm{~d}, \mathrm{~J}=7.6 \mathrm{~Hz}, 2 \mathrm{H}), 7.61(\mathrm{~d}, \mathrm{~J}=6.4 \mathrm{~Hz}, 2 \mathrm{H}), 7.40(\mathrm{t}, \mathrm{J}=7.5 \mathrm{~Hz}, 2 \mathrm{H}), 7.32(\mathrm{t}, \mathrm{J}=7.44 \mathrm{~Hz}, 2 \mathrm{H})$, $6.56(\mathrm{~s}, 1 \mathrm{H}), 5.37(\mathrm{~d}, \mathrm{~J}=7.9 \mathrm{~Hz}, 1 \mathrm{H}), 4.54-4.31(\mathrm{~m}, 3 \mathrm{H}), 4.22(\mathrm{t}, \mathrm{J}=6.9 \mathrm{~Hz}, 1 \mathrm{H}), 3.76(\mathrm{~s}, 3 \mathrm{H}), 3.30(\mathrm{q}, \mathrm{J}=6.28 \mathrm{~Hz}, 2 \mathrm{H}), 1.88$ $(\mathrm{m}, 1 \mathrm{H}), 1.74(\mathrm{~m}, 1 \mathrm{H}), 1.63(\mathrm{~s}, 6 \mathrm{H}), 1.58(\mathrm{~m}, 2 \mathrm{H}), 1.39(\mathrm{~m}, 2 \mathrm{H})$

${ }^{13} \mathrm{C}-\mathrm{NMR}\left(150 \mathrm{MHz}, \mathrm{CDCl}_{3}\right): \delta 172.8,169.1,160.1,156.0,143.9,143.8,141.3,127.7,127.1,125.1,120.0,67.0,61.4(\mathrm{t}, \mathrm{J}=$ $5.5 \mathrm{~Hz}), 53.6,52.5,47.2,39.5,32.1,28.9,27.8(\mathrm{~d}, \mathrm{~J}=4.3 \mathrm{~Hz}), 22.3$

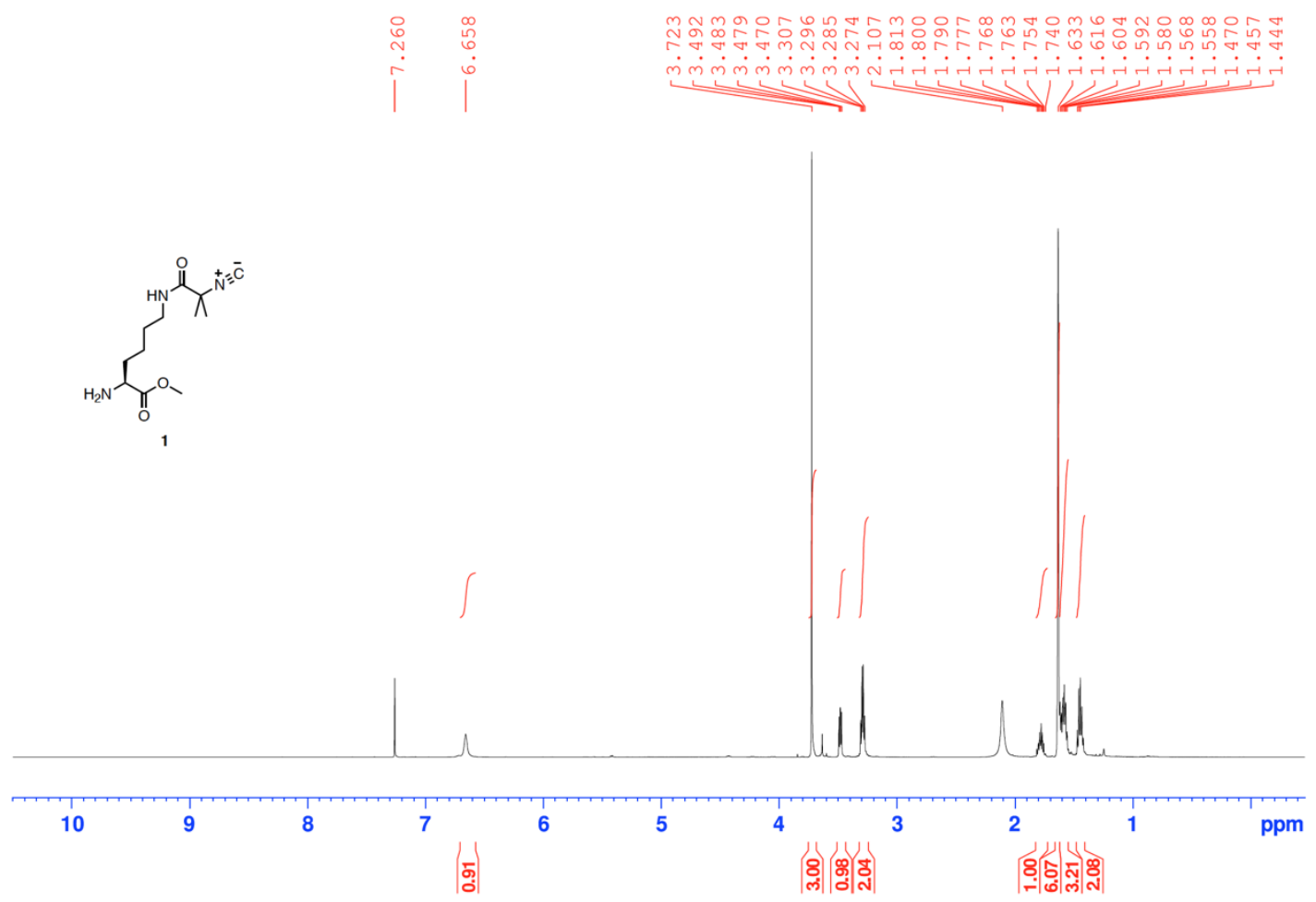


$5(1.06 \mathrm{mg}, 2.2 \mathrm{mmol})$ was treated with $20 \%$ piperidine in $\mathrm{CH}_{2} \mathrm{Cl}_{2}(10 \mathrm{~mL})$ for $1 \mathrm{~h}$, and directly dried under reduced pressure. The crude product was purified by column chromatography ( $5 \% \mathrm{MeOH}$ in $\mathrm{CH}_{2} \mathrm{Cl}_{2}$ ) to yield $\mathrm{NCibK} 1$ as a colorless to slightly yellow oil (380 mg; $67 \%)$. For calculated $[\mathrm{M}+\mathrm{H}]^{+}=256.2$, found $[\mathrm{M}+\mathrm{H}]^{+}=256.1$.

${ }^{1} \mathrm{H}$ NMR $\left(600 \mathrm{MHz}, \mathrm{CDCl}_{3}\right): \delta 6.66(\mathrm{~s}, 1 \mathrm{H}), 3.72(\mathrm{~s}, 3 \mathrm{H}), 3.48\left(\mathrm{dd}, \mathrm{J}=7.6 \mathrm{~Hz}, \mathrm{~J}^{\prime}=5.5 \mathrm{~Hz}, 1 \mathrm{H}\right), 3.29(\mathrm{q}, \mathrm{J}=6.7 \mathrm{~Hz}, 2 \mathrm{H}), 1.78(\mathrm{~m}$, $1 \mathrm{H}$ ), $1.67-1.53(\mathrm{~m}, 9 \mathrm{H}), 1.44$ (quintet, $\mathrm{J}=7.7 \mathrm{~Hz}, 2 \mathrm{H}$ ).

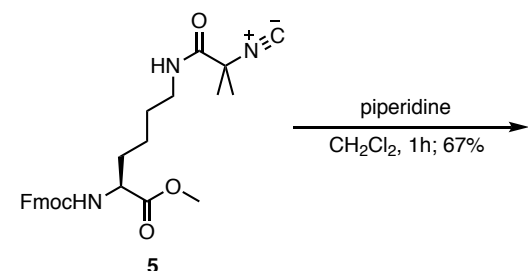<smiles>C=[W]C(=O)NCCCCC(N)=O</smiles>

${ }^{13} \mathrm{C}-\mathrm{NMR}\left(150 \mathrm{MHz}, \mathrm{CDCl}_{3}\right): \delta$ 176.0, 169.0, 160.0, $61.3(\mathrm{t}, \mathrm{J}=5.5 \mathrm{~Hz}), 54.1,52.0,39.8,33.9,28.9,27.8,22.7$.<smiles>C=CC(=O)NCCCC(N)C(=O)OC</smiles>

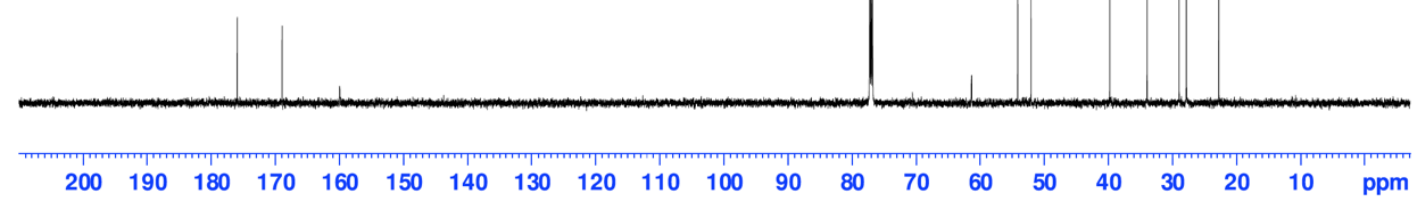

3-isocyanopropyl-1-(4-nitrophenyl)carbonate 7 was synthesized following Tu, J. et al.'s procedure. The solution of 7 (280 $\mathrm{mg}, 1.1 \mathrm{mmol}$ ) in $3 \mathrm{~mL}$ DMF was added to N,N-diisopropylethylamine ( $542 \mathrm{mg}, 0.73 \mathrm{~mL}, 4.2 \mathrm{mmol}$ ) followed by Fmoc-LysOMe. $\mathrm{HCl} 6(535 \mathrm{mg}, 1.3 \mathrm{mmol}$ ) and stirred at room temperature for $2 \mathrm{~h}$. The DMF was removed under reduced pressure. The crude product was washed by water to remove residual Fmoc-Lys-OMe. The precipitant was filtered and dried under vacuum to get 8 as a white solid $(375 \mathrm{mg} ; 68 \%)$. For calculated $[\mathrm{M}+\mathrm{H}]^{+}=494.2$, found $[\mathrm{M}+\mathrm{H}]^{+}=494.2$. 
${ }^{1} \mathrm{H}$ NMR $\left(600 \mathrm{MHz}, \mathrm{CDCl}_{3}\right): \delta 7.77(\mathrm{~d}, \mathrm{~J}=7.6 \mathrm{~Hz}, 2 \mathrm{H}), 7.61(\mathrm{t}, \mathrm{J}=7.6 \mathrm{~Hz}, 2 \mathrm{H}), 7.41(\mathrm{t}, \mathrm{J}=7.4 \mathrm{~Hz}, 2 \mathrm{H}), 7.32(\mathrm{t}, \mathrm{J}=7.4 \mathrm{~Hz}, 2 \mathrm{H})$, 4.54-4.33 (m, 3H), 4.27-4.15 (m, 3H), $3.76(\mathrm{~s}, 3 \mathrm{H}), 3.45(\mathrm{~s}, 2 \mathrm{H}), 3.18(\mathrm{~d}, \mathrm{~J}=6.1 \mathrm{~Hz}, 2 \mathrm{H}), 2.04(\mathrm{~s}, 1 \mathrm{H}), 1.96(\mathrm{~m}, 2 \mathrm{H}), 1.87(\mathrm{~m}$, $1 \mathrm{H}), 1.70(\mathrm{~m}, 1 \mathrm{H}), 1.58(\mathrm{~m}, 1 \mathrm{H}), 1.54(\mathrm{~m}, 2 \mathrm{H}), 1.39(\mathrm{~m}, 2 \mathrm{H})$.

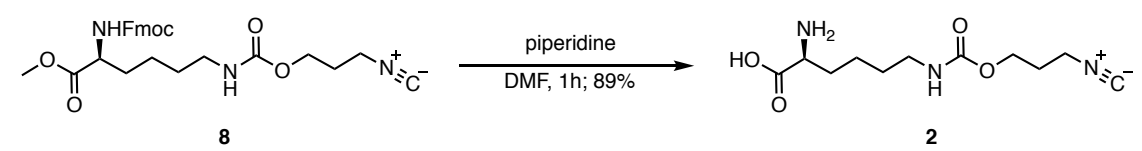

$8(375 \mathrm{mg}, 0.76 \mathrm{mmol})$ was treated with $20 \%$ piperidine in DMF $(0.5 \mathrm{~mL})$ for $1 \mathrm{~h}$ and directly dried under reduced pressure. The crude product was washed by ether, filtered, and dried under vacuum to yield NCK 2 as a white solid (174 mg; 89\%). For calculated $[\mathrm{M}+\mathrm{H}]^{+}=258.1$, found $[\mathrm{M}+\mathrm{H}]^{+}=258.1$.

${ }^{1} \mathrm{H}$ NMR (600 MHz, DMSO-d $\left.\mathrm{d}_{6}\right): 87.46(\mathrm{br}, 2 \mathrm{H}), 7.14(\mathrm{t}, \mathrm{J}=5.1 \mathrm{~Hz}, 1 \mathrm{H}), 4.01(\mathrm{t}, \mathrm{J}=6.2 \mathrm{~Hz}, 2 \mathrm{H}), 3.55(\mathrm{t}, \mathrm{J}=6.3 \mathrm{~Hz}, 2 \mathrm{H}), 3.07$ $(t, J=5.9 \mathrm{~Hz}, 1 \mathrm{H}), 2.95(\mathrm{q}, \mathrm{J}=6.4 \mathrm{~Hz}, 2 \mathrm{H}), 3.55(\mathrm{t}, \mathrm{J}=6.3 \mathrm{~Hz}, 2 \mathrm{H}), 1.87(\mathrm{~m}, 2 \mathrm{H}), 1.67(\mathrm{~m}, 1 \mathrm{H}), 1.54(\mathrm{~m}, 1 \mathrm{H}), 1.36(\mathrm{~m}, 2 \mathrm{H})$, $1.30(\mathrm{~m}, 2 \mathrm{H})$

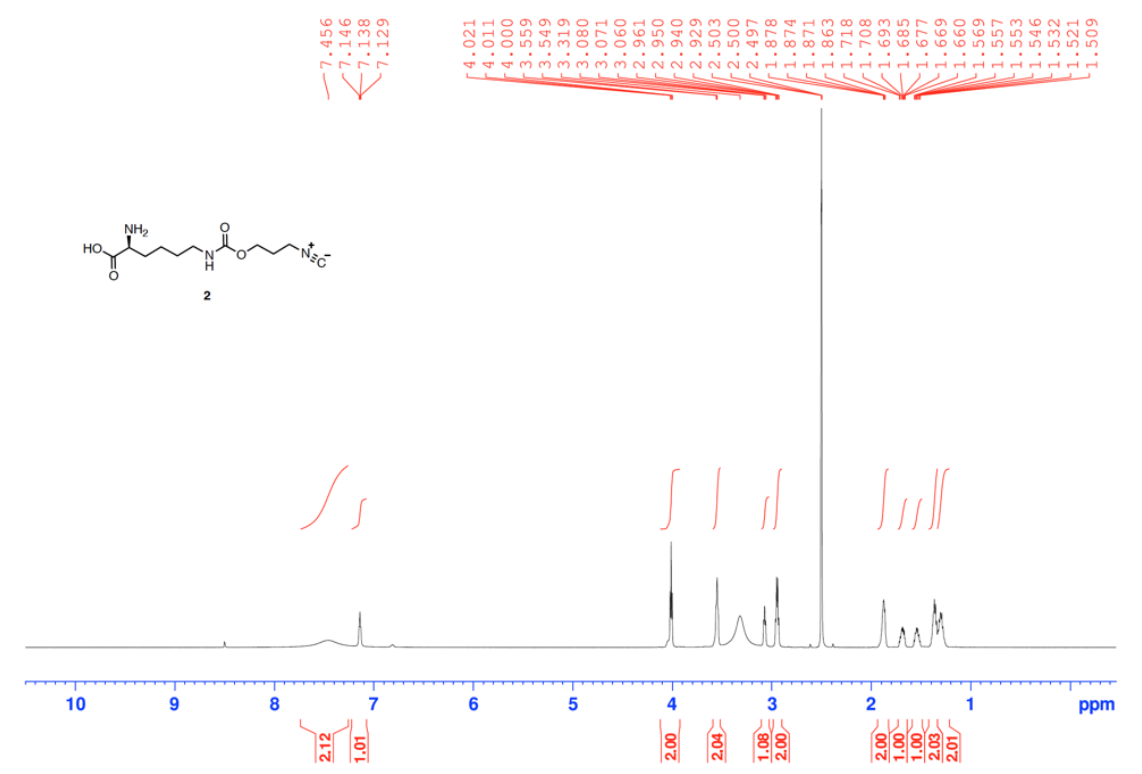

${ }^{13} \mathrm{C}-\mathrm{NMR}\left(150 \mathrm{MHz}, \mathrm{DMSO}-\mathrm{d}_{6}\right): \delta$ 169.8, 156.1, 155.9, 60.1, 54.1, 40.1, 38.3, 30.8, 29.1, 28.3, 22.4. 


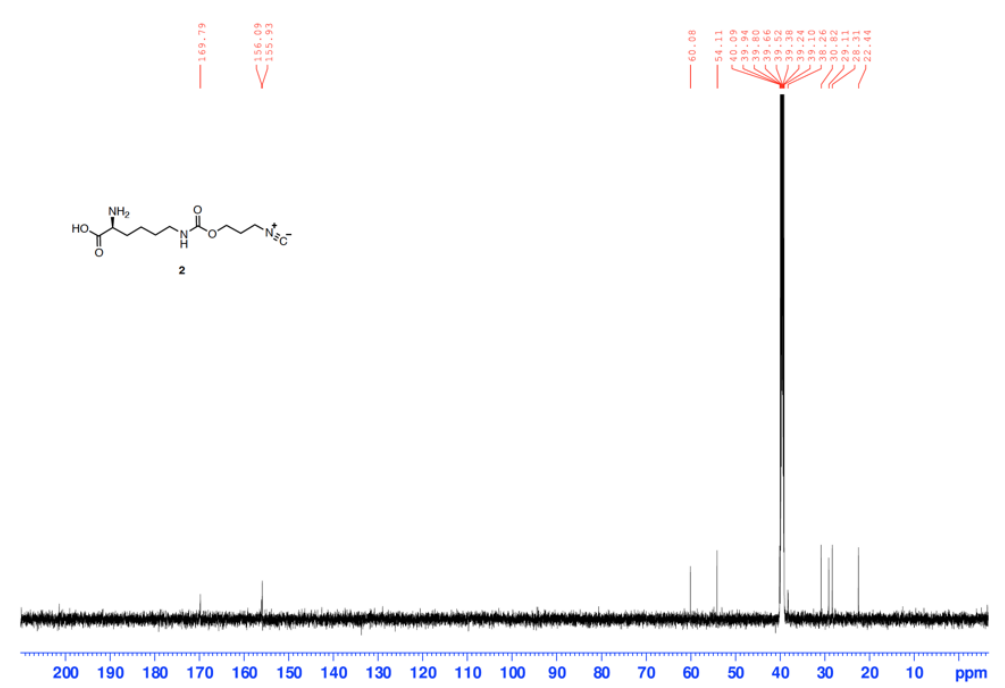

\section{Plasmid Construction}

The ChPyIRS(IPYE)/MbPyIRS(IPYE)gene was amplified from pTech-chPyIRS(IPYE) with forward primer PJ37 and reverse primer PJ38/PJ39, and inserted into pUltra plasmid using the Notl restriction sites to generate pUltra-ChPyIRS(IPYE)/ pUltra-MbPyIRS(IPYE) via Gibson assembly. To create PAcBac-ChPyIRS(IPYE), ChPyIRS(IPYE) was generated using PJ40 and PJ41 and inserted into Nhel and NcoRI-digested pAcBac plasmid. The pNICE-LAP-neurexin-1beta mutant K6(LAP)TAG was generated by site directed mutagenesis using Da153.

\section{Reaction of isocyanides with BODIPY-Tz}

1 mM DMSO solution of BODIPY- $m$-Tz or BODIPY- $p$-Tz and 100 mM NCibK PBS buffer (pH=7.4) was diluted by PBS (pH=7.4) to the final concentration of $100 \mathrm{nM}$ and $1000 \mathrm{uM}$, respectively. Fluorescence intensity scanning is measured at $0,1,30$, $60,120,180,240,300,360,480,540,720$ minutes with triple repetition (Ex $475 \mathrm{~nm} /$ Em $485-600 \mathrm{~nm}$ ). Turn-on fold is relative to the zero-minute fluorescence intensity. All the fluorescence intensities have been normalized by subtracting the background (cuvette with only PBS).

\section{Rate Determination for NCibK Reaction with dpTz}

NCibK \& dp-Tz stock solution was prepared in PBS buffer (pH 7.4) and DMSO respectively. The reaction was initiated by mixing and diluting NCibK and dp-Tz stock solution with PBS buffer at a final concentration of $6 \mathrm{mM}$ and $0.6 \mathrm{mM}(6 \% \mathrm{v} / \mathrm{v}$ DMSO in PBS), respectively. NCibK at concentration $9 \mathrm{mM}$ and $12 \mathrm{mM}$ was also conducted. The formation of the product was tracked by measuring its absorption peak at $430 \mathrm{~nm}$ once per 10 second over the reaction timeframe by using a EVOLUTION 220 UV-Visible spectrophotometer (Thermo Scientific). Samples were measured in a $1 \mathrm{~cm}$ pathlength quartz cuvette at room temperature $\left(25^{\circ} \mathrm{C}\right)$. Reaction rates were obtained by fitting the exponential growth of absorption intensity as a pseudo first order reaction. All the data were performed with GraphPad Prism.

\section{Protein Expression and Purification from E. coli.}

E. coli. BL21(DE3) cells were co-transformed with protein expression plasmid(pET22b-T5-sfGFP151*/pBad-myo99TAG) and NCK/NCibK incorporation plasmids and grown in LB medium supplemented with or without $1 \mathrm{mM} \mathrm{NCK/NCibK.} \mathrm{Protein}$ 
expression was induced by the addition of isopropyl- $\beta$-D-thiogalactoside (IPTG) to a final concentration of $1 \mathrm{mM}$ at OD 0.6 and cells were grown for an additional $20 \mathrm{~h}$ at $30^{\circ} \mathrm{C}$. Cells were harvested by centrifugation at $4,750 \times \mathrm{g}$ for $10 \mathrm{~min}$. The cell pellets were suspended in lysis buffer ( $30 \mathrm{mM}$ Tris-HCl buffer with $20 \%$ sucrose, $1 \mathrm{mM}$ EDTA, $0.2 \mathrm{mg} / \mathrm{mL}$ lysozyme, and $0.1 \%$ benzonase, $\mathrm{pH} 7.4$ ) and lysed at $37^{\circ} \mathrm{C}$. The resulting cell lysate was clarified by centrifugation at $14,000 \times \mathrm{g}$ for $30 \mathrm{~min}$, and protein was purified on Ni-NTA resin (Qiagen) following the manufacturer's instructions. LpIA(W37V) was expressed and purified according to the Reference. ${ }^{2}$

\section{Expression and Fluorescence Measurement of sfGFP}

After sfGFP expression with the same method described above, $0.25 \mathrm{~mL}$ cells were harvested by centrifugation at 4,750 $\times \mathrm{g}$ for $10 \mathrm{~min}$ and washed with PH 7.4 phosphate buffer. Then, cells pellets were re-suspended at $1 \mathrm{ml} \mathrm{PH} 7.4$ phosphate buffer and $200 \mu \mathrm{l}$ was used to measure fluorescence (excitation/emission wavelength: 395/509 nm) and OD600.

\section{Expression of EGFP at HeLa Cells}

Adherent HeLa cells were cultured in DMEM medium supplemented with 10\% FBS and $0.5 \%$ antibiotic-antimycotic at $37{ }^{\circ} \mathrm{C}$ in a humidified chamber with $5 \% \mathrm{CO}_{2}$. After seeding at 24 -well plate with $80 \%$ confluency, Hela cells were transfected with pAcBac-EGFP* and pAcBac-chPyl (IPYE) using Polyject transfection reagent in the absence of ncAA. Medium was changed to new media with or without $0.75 \mathrm{mM} \mathrm{NCK/NCibK/BocK} \mathrm{at} 12 \mathrm{~h}$ post-transfection and images were taken at $60 \mathrm{~h}$ post-transfection.

\section{Expression of EGFP at HEK293T Cells}

Adherent HEK293T cells were cultured in the same conditions with the Hela cells. After seeding a 24-well plate with appropriate confluency, cells were transfected with pAcBac-EGFP* and PAcBac-chPyI(IPYE) using PolyJet transfection reagent in the presence or absence of ncAAs. Medium was changed to new media with or without $0.75 \mathrm{mM} n c A A$ at $12 \mathrm{~h}$ post-transfection and images were taken at $36 \mathrm{~h}$ post-transfection.

\section{SfGFP-NCK reaction with dpTz}

$1 \mathrm{mM}$ dpTz was added to $100 \mu \mathrm{M}$ sfGFP-151NCK in a PH 7.4 phosphate buffer at $37^{\circ} \mathrm{C}$ for 8 hours, followed by removal of excess dpTz using Amicon 5,000 molecular-weight-cutoff protein concentrator.

\section{Decaging of neurexin-1beta at HEK293T Cells}

HEK293T cells were transfected with pNICE-LAP-neurexin-1beta or co-transfected with pNICE-LAP-neurexin-1beta-TAG and pAcBac-ChPy1RS (IPYE) for $18 \mathrm{~h}$. The cell culture was changed to new DMEM (10\% FBS) containing $0.7 \mathrm{mM}$ NCK at $18 \mathrm{~h}$ post transfection to allow protein expression for another $24 \mathrm{~h}$. Before decaging, the cells were incubated in new DMEM media $(10 \% \mathrm{FBS})$ at $37^{\circ} \mathrm{C}$ for $1 \mathrm{~h}$ to remove a remaining NCK. The cells were treated with $1 \mathrm{mM} \mathrm{dpTz}$ at PBS7.4 for $20 \mathrm{~min}$, followed by incubation in DMEM media (10\% FBS) containing $1 \mathrm{mM}$ pyrrolidine for $8 \mathrm{~h} .{ }^{3,4}$ After decaging, a LAP assay was performed by incubating cells with $10 \mathrm{uM}{ }^{\text {W37V }}{ }^{\text {LpIA, }} 50 \mathrm{uM}$ coumarin substrate, $1 \mathrm{mM}$ ATP and $2 \mathrm{mM} \mathrm{Mg}(\mathrm{OAc})_{2}$ in $50 \mathrm{mM} \mathrm{Na}_{2} \mathrm{HPO}_{4} \mathrm{pH} 7.2$, followed by cell fixation with pre-cooled methanol. Myc tag immunofluorescence staining was performed by applying $0.1 \mathrm{ug} / \mathrm{mL}$ anti-myc antibody to cells at $37^{\circ} \mathrm{C}$ for $2 \mathrm{~h}$. After washing, cells were incubated with FITCconjugated secondary antibody $(7.5 \mathrm{ug} / \mathrm{ml})$ for $1 \mathrm{~h}$. Nucleus staining was performed right before imaging by incubating cells with 5UM DRAQ5 for $10 \mathrm{~min}$. 


\begin{tabular}{|l|l|}
\hline Oligonucleotide & Sequence $\left(5^{\prime}\right.$ - $^{\prime}$ ) \\
\hline Da153 & ggaggacctgggcttcgagatcgacTAGgtgtggcacgacttccccgccacta \\
\hline PJ37 & TTCACAAAGGAGGTGCGGCCGCatggataagaagccgctggatgttctg \\
\hline PJ38 & $\begin{array}{l}\text { GAGACCGTTTAAACGCGGCCGCTTACAGGTTGGTAGAAATCCC } \\
\text { GTTATAGTAAGAC }\end{array}$ \\
\hline PJ39 & $\begin{array}{l}\text { GAGACCGTTTAAACGCGGCCGCTTACAGGTTGGTAGAGATACC } \\
\text { GTTGTAGTAAG }\end{array}$ \\
\hline PJ40 & AGGGAGACCCAAGCTGGCTAGCGCCACCatggataagaagccgctggatgttctg \\
\hline PJ4 & gtcgacttaacgcgttgaattcTTACAGGTTGGTAGAAATCCCGTTATAGTAAGAC \\
\hline
\end{tabular}

Table S1. DNA oligomers
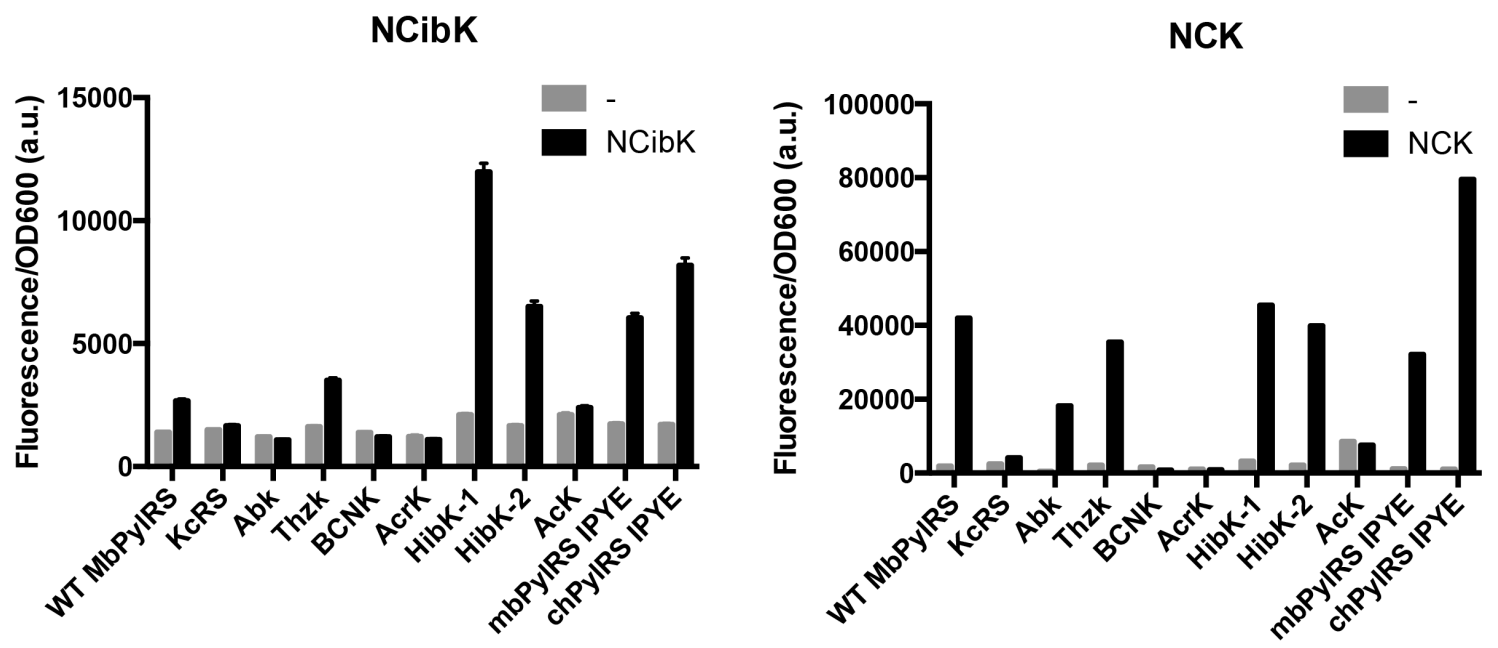

Figure S1. Screening of PyIRS mutants for NCibK and NCK incorporation.

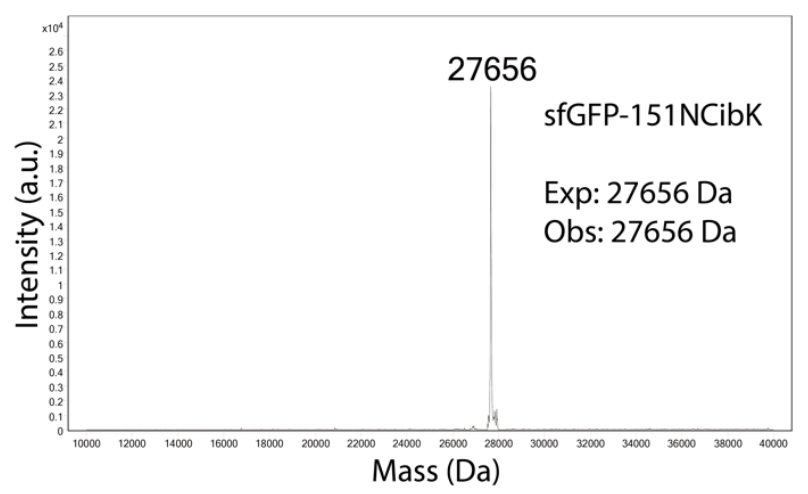

Figure S2. ESI-MS analysis of isolated sfGFP-NCibK expressed from M9-glucose minimal medium. 

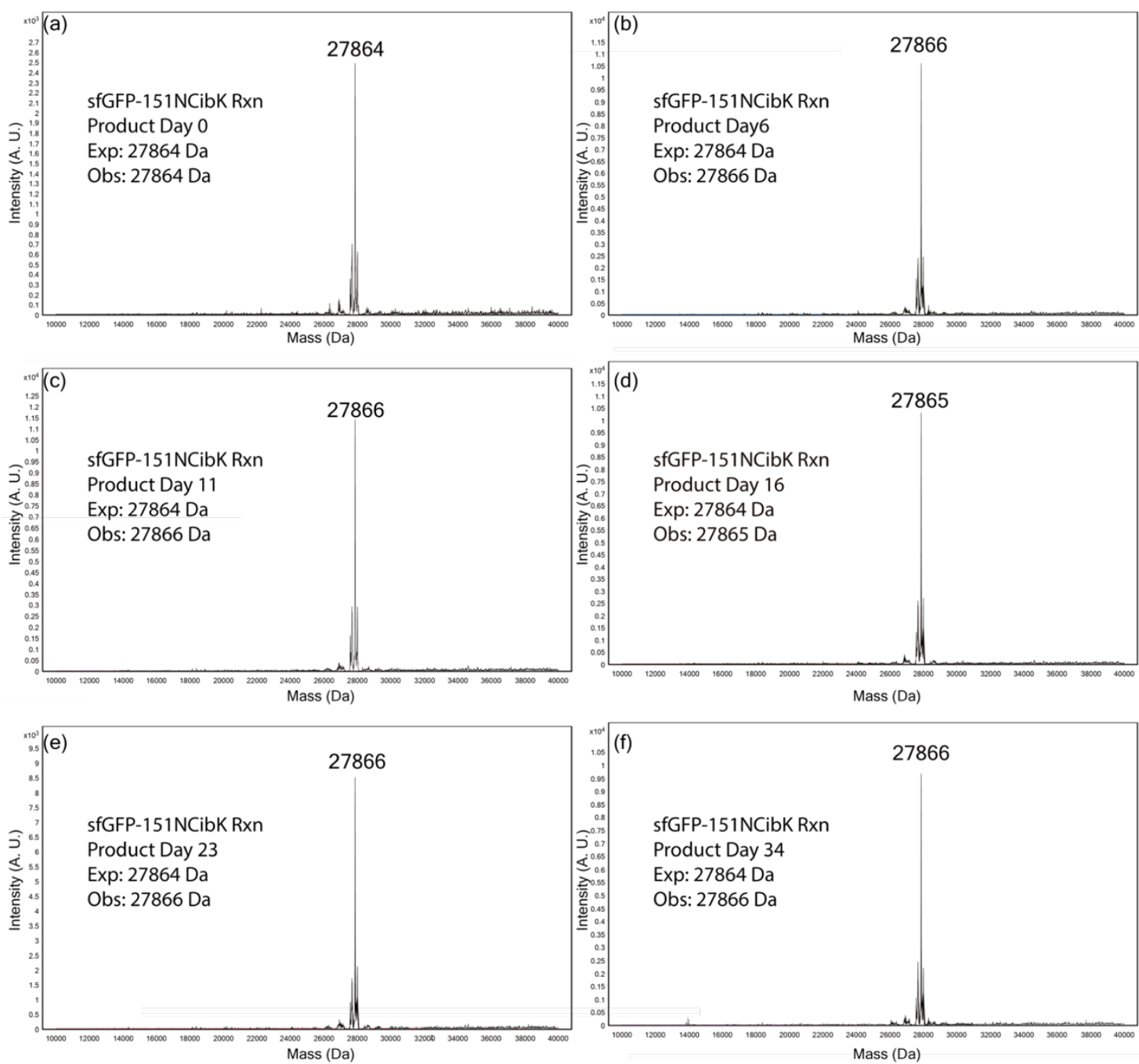

Figure S3. Stability of sfGFP-NCibK conjugate with dpTz. 


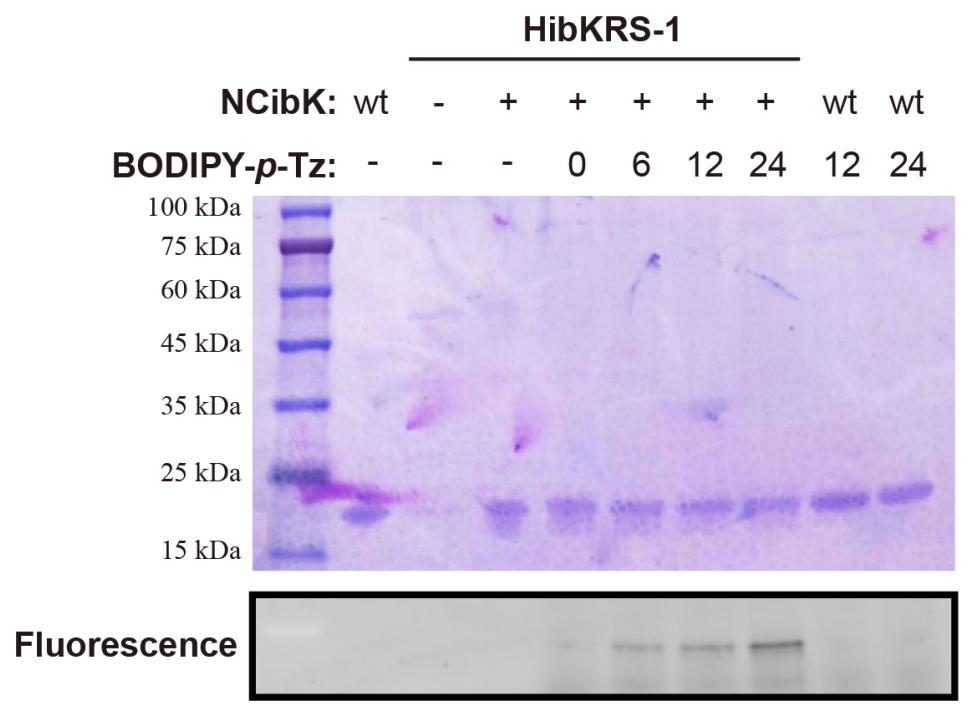

Figure S4. Incorporation of NCibK into Myoglobin.SDS-PAGE analysis of NCibK-Myoglobin labelled with BODIPY-p-Tz in different reaction time $(0,6,12,24 \mathrm{~h})$. Fluorescence signals showed that BODIPY- $p$-Tz only specifically labelled NCibK-Myoglobin compared to WTMyoglobin. 

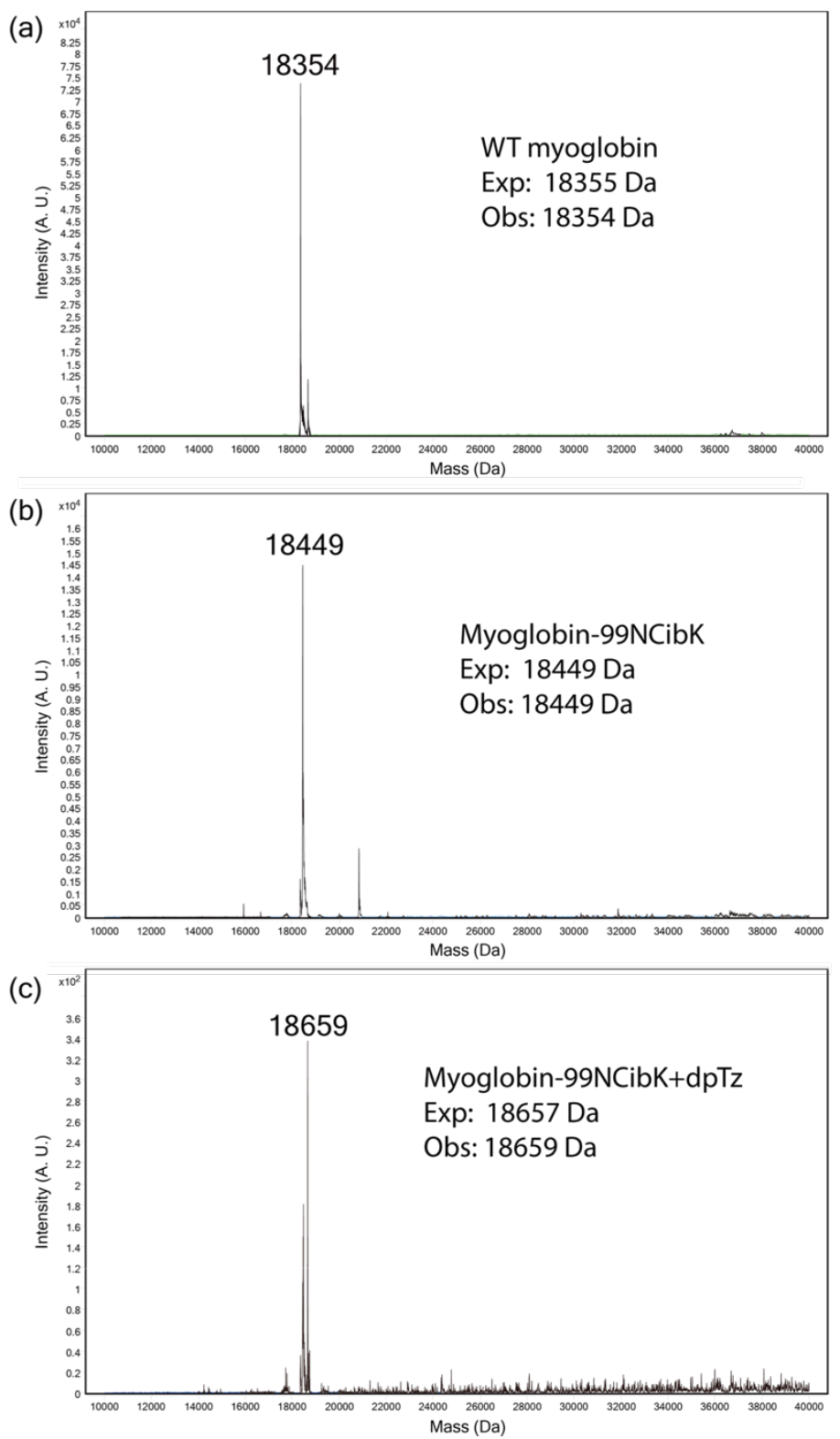

Figure S5. Incorporation of NCibK into Myoglobin

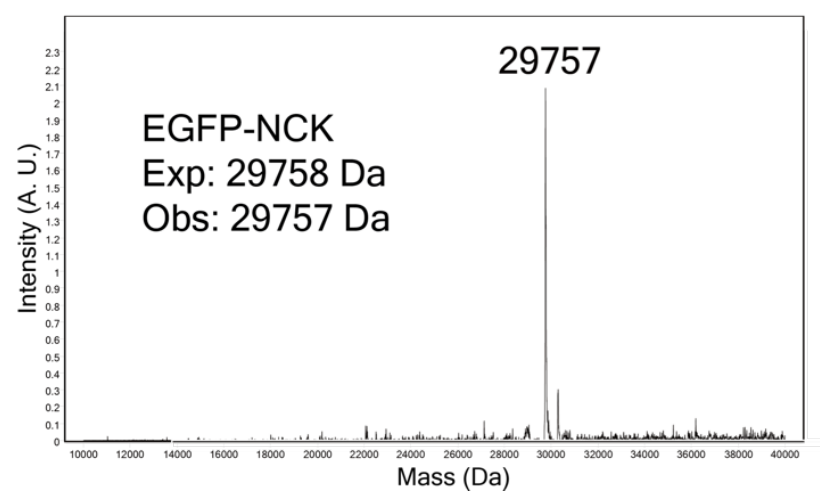

Figure S6. Incorporation of NCK into EGFP in HEK293T cells. 


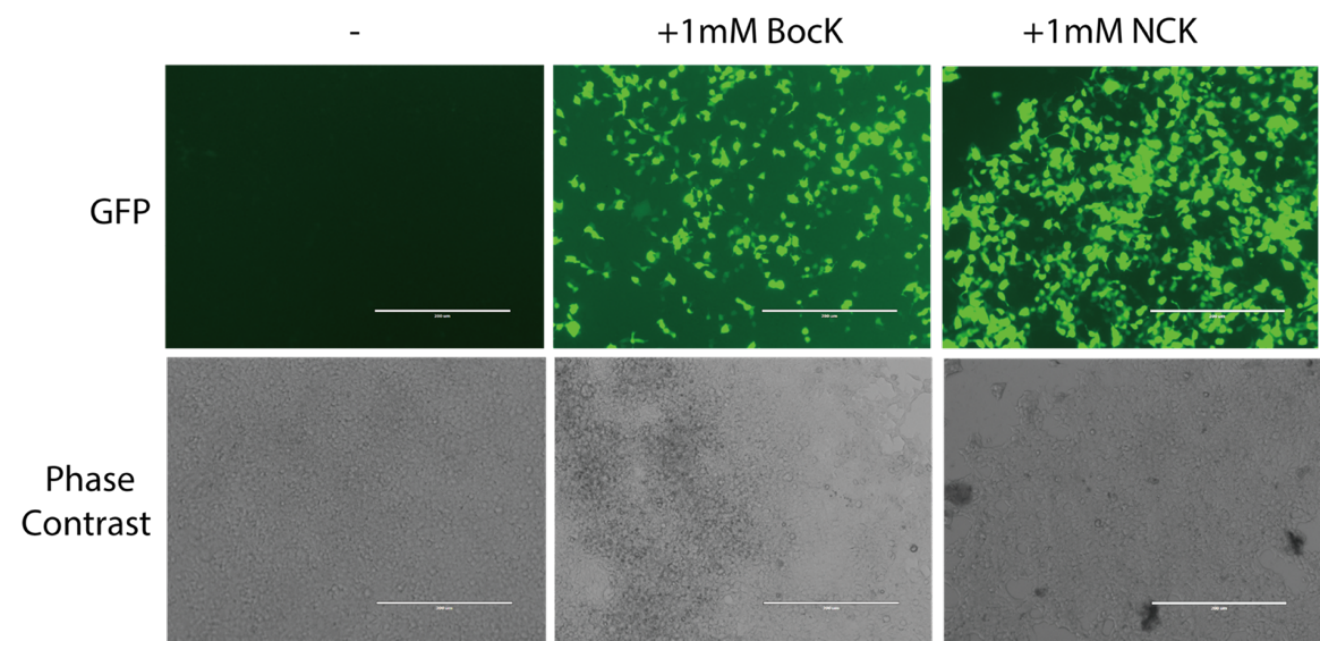

Figure S7. Incorporation of BocK, NCK into EGFP-Y40TAG in HEK293T Cells analyzed by fluorescence microscopy in the presence of or absence (-) of ncAAs. 


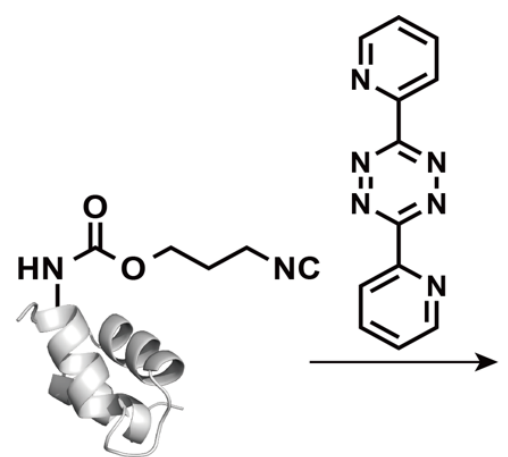

Exp: $27672 \mathrm{Da}$

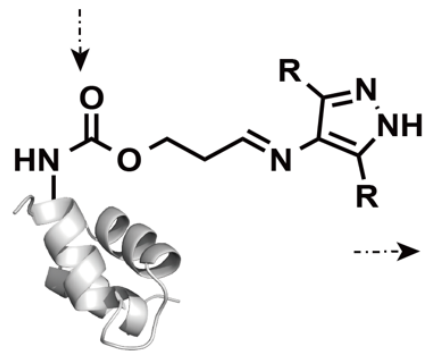

Exp: $27880 \mathrm{Da}(\mathrm{d})$

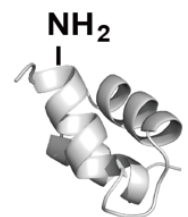

Exp: $27561 \mathrm{Da}(\mathrm{a})$

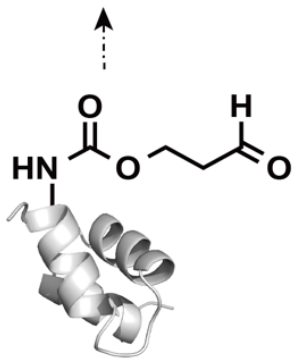

Exp: $27661 \mathrm{Da}(\mathrm{e})$
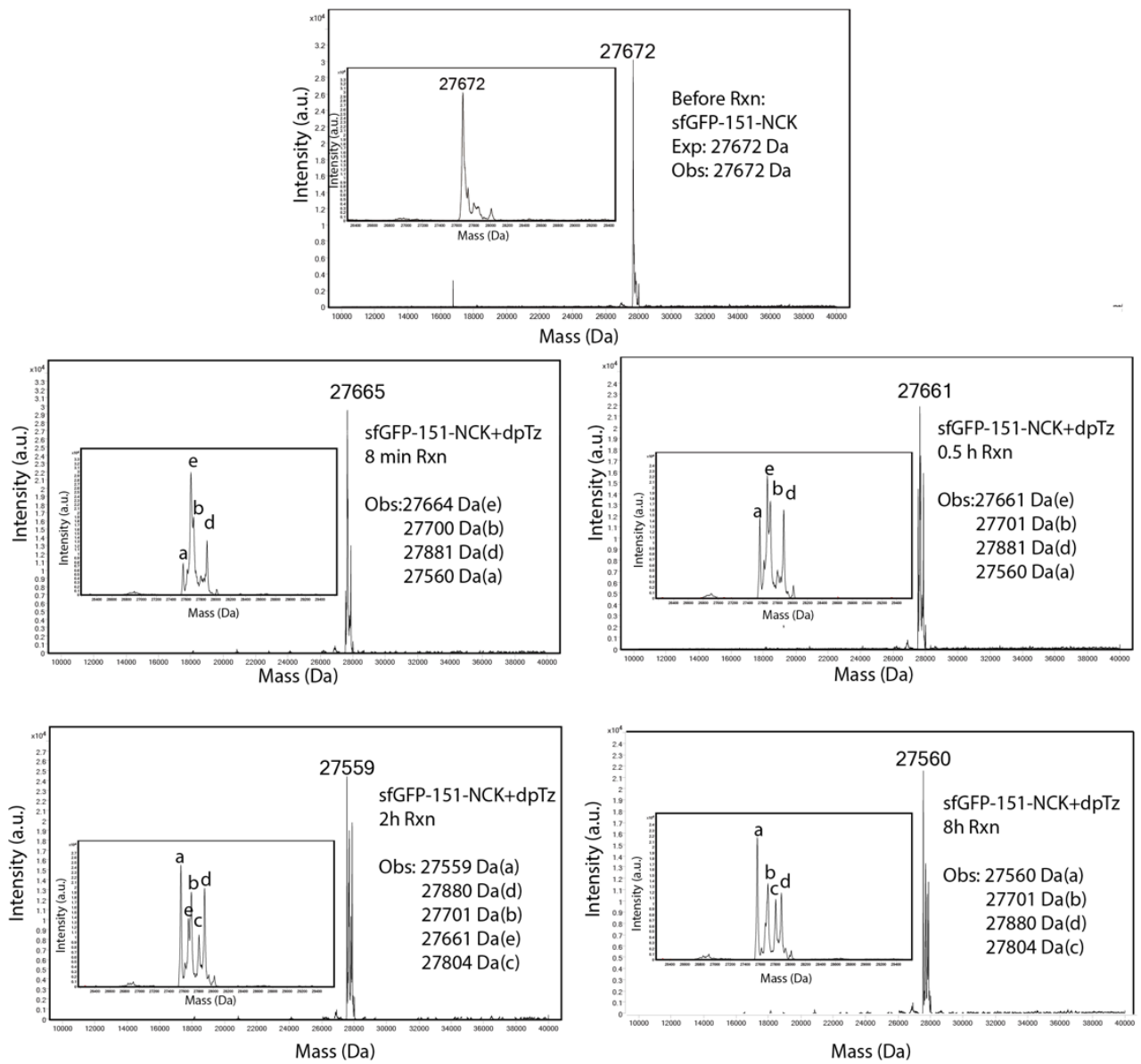

Figure S8. Time-dependent study of tetrazine-mediated sfGFP-NCK decaging. Peaks a, $d$, and e, represent the final decaged product (27560 Da), pyrazole-imine intermediate (27881 Da), and 3-oxopropyl-caged intermediate (27661 Da), respectively. Peaks c and d are likely additive products derived from the aldehyde intermediate (peak e, $27661 \mathrm{Da}$ ). 

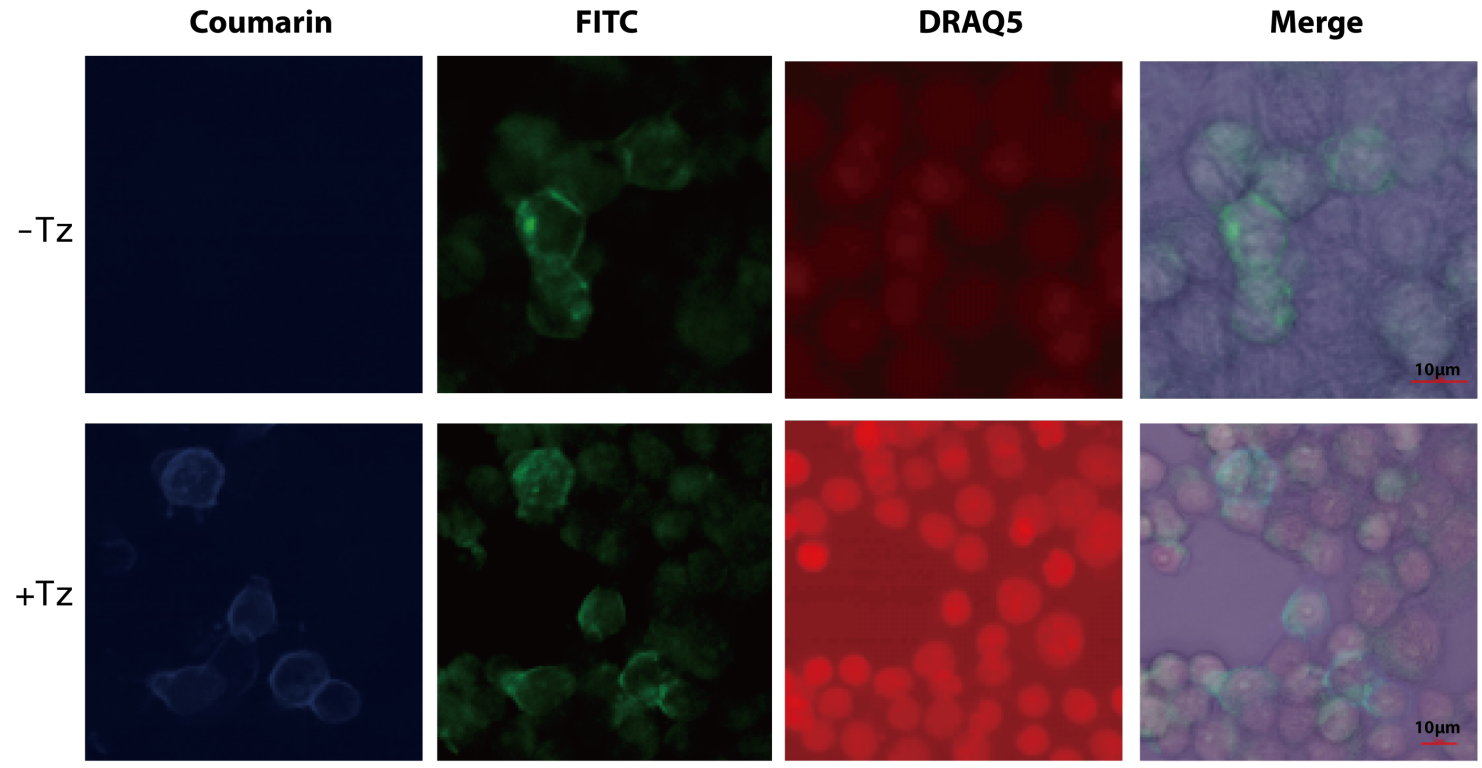

Figure 59. Tetrazine-mediated LAP tag activation in living cells. HEK293T cells expressing NCKcontaining NRX-LAP were mixed with PBS with $(+\mathrm{Tz})$ or without $(-\mathrm{Tz}) 1 \mathrm{mM}$ dpTz in for 20 mins, followed by the incubation with $1 \mathrm{mM}$ pyrrolidine for $8 \mathrm{~h}$. After PRIME labeling (blue) and cell fixation, $0.1 \mu \mathrm{g} / \mathrm{mL}$ anti-Myc antibody for $1 \mathrm{~h}$ and $7.5 \mu \mathrm{g} / \mathrm{mL}$ FITC-conjugated secondary antibody (green) were added to the cells to check the expression of NRX-LAP. Nucleus staining was carried out with $5 \mu \mathrm{M}$ DRAQ5 (red) right before confocal imaging. Scale bars $=10 \mu \mathrm{m}$. 


\section{References}

1 X. Bi, K. K. Pasunooti, A. H. Tareq, J. Takyi-Williams and C.-F. Liu, Organic \& Biomolecular Chemistry, 2016, 14, 5282-5285.

2 C. Uttamapinant, K. A. White, H. Baruah, S. Thompson, M. Fernández-Suárez, S. Puthenveetil and A. Y. Ting, Proc. Natl. Acad. Sci. U.S.A., 2010, 107, 10914-10919.

3 A. K. Leslie, D. Li and K. Koide, J. Org. Chem., 2011, 76, 6860-6865.

4 A. L. Garner, C. M. S. Croix, B. R. Pitt, G. D. Leikauf, S. Ando and K. Koide, Nature Chem, 2009, 1, 316-321. 